\title{
A aclaração da fenomenologia a partir da questão do ser em Heidegger
}

\section{The clarification of phenomenology from the question of being in Heidegger.}

\author{
Marcos Aurélio Fernandes \\ Departamento de Filosofia - PPGFIL UnB \\ framarcosaurelio@hotmail.com
}

\section{Resumo}

Trata-se de uma exposição transversal da fenomenologia em Heidegger. Apresenta-se a fenomenologia em sua nova configuração, dada por Heidegger ao longo de todo seu caminho de pensamento, e não somente em sua fase inicial, enquanto método da ontologia compreendida como questão do sentido (da verdade) do ser. Num segundo momento apresenta-se a "coisa mesma" da fenomenologia como a "clareira do ser". A aclaração do método caminha pari passu com a aclaração da coisa mesma do pensar. $O$ pensamento filosófico se realiza como ciência ontológica. As ciências ônticas, positivas, estão fundamentadas na compreensão (pré-)ontológica. A fenomenologia retorna da positividade do ente à transcendentalidade. A coisa mesma da fenomenologia se abre na dimensão da transcendentalidade. Porém, a consciência intencional em seu a priori, tomada no sentido da subjetividade transcendental, é, ela mesma fenomenal. A fenomenalidade da consciência deixa aparecer e transparecer nela mesma o ser desencoberto e o desencobrimento: a "alétheia". Na experiência da clareira (Lichtung) da verdade do ser se doa o arqui-fenômeno (Ereignis), a coisa mesma da fenomenologia.

Palavras-chave: fenomenologia, ser, verdade, clareira, Heidegger.

\section{Abstract}

This is a transversal exposition of phenomenology in Heidegger. It presents phenomenology in its new configuration, given by Heidegger throughout his entire thought path, and not only in its initial phase, as a method of ontology understood as a question of the sense (the truth) of being. In a second moment, the "thing itself" of phenomenology is presented as the "clearing (lighting-process) of being". The clarification of the method goes pari passu with the clarification of the very thing (the task) of 
thinking. Philosophical thinking is realized as ontological science. The ontic, positive sciences are founded on (pre)ontological understanding. Phenomenology returns from the positivity of the being to transcendentality. The very thing of phenomenology opens in the dimension of transcendentality. However, intentional consciousness in its a priori, taken in the sense of transcendental subjectivity, is itself phenomenal. The phenomenality of consciousness lets appear and transpire in itself the non-concealment and the revealing: the "alétheia". In the experience of the clearing or lighting-process (Lichtung) of truth of being, the arch-phenomenon (Ereignis), the very thing of phenomenology, is given.

Keywords: phenomenology, being, truth, clearing (lighting-process), Heidegger.

"Só o obscuro nos cintila"

Manoel de Barros

(Livro sobre nada)

\section{A fenomenologia fundada na questão do ser.}

Heidegger, desde os primeiros passos de seu caminho de pensamento, procura realizar uma meditação radical a respeito da pesquisa fenomenológica nela mesma, exercendo uma crítica imanente, e tentando, ao mesmo tempo, ir além dela, colocando-a sobre uma nova dimensão, que é a da questão do sentido do ser.

Em Husserl, a ideia da fenomenologia tem seu fio condutor na proposta de um retorno (Rückgang) à consciência. Heidegger resume esta proposta assim:

A aclaração (Klärung) fundamental da necessidade do retorno à
consciência, a determinação radical e explícita do caminho e das
leis de etapas desse retorno, a delimitação em linha de princípio
e a perscrutação sistemática do campo da pura subjetividade que
se abre com base neste retorno se chama fenomenologia
(HEIDEGGER, 1968, p. 256).

Do ponto de vista de Heidegger, este retorno proposto pela fenomenologia husserliana se põe na esteira da tradição filosófica. Aparentemente a filosofia não tem como as ciências positivas, um campo próprio de pesquisa. As diversas ciências positivas obtêm as suas regiões objetuais a partir do todo do ente (natureza, história, espaço...). Estas são ciências ônticas. Elas, a cada vez, se dirigem ao ente desta ou daquela região objetual, ao seu modo. $O$ todo do ente parece, pois, já distribuído entre as ciências positivas (ônticas, objetivas). Não 
parece restar nada para a filosofia. Entretanto, desde os seus primórdios, a filosofia se projetou como a ciência fundamental e como a ciência universal do ente. $O$ ente é o objeto da filosofia. Entretanto, não o ente enquanto restrito a esta ou aquela região particular (o ente movente, o ente vivente, o ente agente, etc.), mas o ente enquanto ente, como outras palavras, o ente na perspectiva do ser. Filosofia não é ciência ôntica, mas sim ciência ontológica. Fenomenologia aparece, então, como conceito de método. Fenomenologia diz método filosófico. É método para investigar o que constitui o tema da filosofia: o ente enquanto ente. Fenomenologia é método de investigação da ontologia, não apenas como ontologia regional, mas como ontologia universal e fundamental.

Acontece, porém, que, na tradição, a filosofia investiga o ente enquanto ente, isto é, o ente no tocante a e na perspectiva de seu ser, de tal modo que a iluminação, isto é, a aclaração do ser se dá através de uma meditação a respeito do pensar. Ser (enquanto entidade do ente) e pensar é o título que resume a história da filosofia primeira, da ontologia, enfim, da metafísica. Como num contraponto, em Heidegger, o pensamento segue pela vida questionamento de ser (enquanto diferença ontológica) e tempo, conforme recorda-nos as anotações feitas por Heidegger em 1936 a Ser e Tempo, publicadas no volume 82 da edição completa de seus textos (HEIDEGGER, 2018, p. 7).

A conexão (copertença) de ser e pensar já aparece em Parmênides. Só que ali o pensar está sob a égide do ser. Depois de Platão, na metafísica, o ser é que vai estar sob a égide do pensar. Em Platão, de fato, o ser, no sentido da entidade do ente, a "ousía", torna-se "eidos", "ideia". O desvelamento das ideias é orientado pelo "lógos", isto é, pelo auto diálogo da alma consigo mesma. A "ousía", o ser tomado no sentido da entidade do ente, se deixa investigar sob a égide do pensar também em Aristóteles, em que o "lógos" como enunciar e enunciado do conhecimento racional, leva a ontologia a se cumprir a partir do fio condutor das categorias. Na modernidade, a entidade do ente passa a ser concebida como a objetualidade do objeto, desde o pensar, como "eu penso" (ego cogito, ich denke). Descartes funda a filosofia primeira (prima philosophia) sobre a "res cogitans". Também a problemática transcendental de Kant se movimenta no campo da consciência (Bewusstsein). Por último, a fenomenologia proposta por Husserl tem como escopo a iluminação do ser do ente tendo como 
fio condutor o retorno à consciência intencional, tomada no sentido da subjetividade transcendental: filosofia fenomenológica como nova e original, concreta mathesis universalis, como ontologia universal.

Para Heidegger, em toda a sua história, a filosofia questionou o ser do ente, sua entidade. A pergunta pelo ser do ente (entidade) é a sua questão condutora (Leitfrage). Contudo, a questão pelo sentido do ser, ou melhor, pela verdade (revelação) do ser, questão fundamental (Grundfrage), não fora posta. A questão Ser e Tempo se move desde esta necessidade. Como Heidegger indica em Meu caminho na fenomenologia, de 1963, desde a leitura da dissertação de Brentano, Da multifária significação do ente segundo Aristóteles (Von der mannigfachen Bedeutung des Seienden nach Aristóteles), de 1862, tal questão fundamental emergiu de modo seminal. De início, na leitura de Brentano, ela aparece como a pergunta pela significação fundamental condutora (die leitende Grundbedeutung) da multifária significação do ente. Irrompe, pois, como a pergunta: "o que significa ser? (Was heisst Sein?)" (HEIDEGGER, 1988, p. 81).

É a partir daí que nasce, cresce, rebenta a questão fundamental, que, em Ser e Tempo, de 1927, chega a uma maturação decisiva. No §2, discute-se "a estrutura formal da pergunta pelo ser" (HEIDEGGER, 1993b, p. 5-8). Ela parte do "faktum" da compreensão de ser mediana e vaga da cotidianidade, vigente em nossos discursos em cada dizer "é". Três momentos articulam a estrutura da questão do ser: o questionado (das Gefragte), o interrogado (das Befragte) e o inquirido (das Erfragte). O questionado (das Gefragte) da pergunta é "o ser, aquilo que determina o ente enquanto ente, aquilo, com vistas a que o ente, como quer que sempre ele é discutido, a cada vez já é compreendido" (HEIDEGGER, 1993b, p. 6). "Ser", aqui, nomeia a diferença ontológica. Por isso Heidegger, ato contínuo, diz: "O ser do ente não 'é' ele mesmo um ente" (HEIDEGGER, 1993b, p. 6). Em Ser e Tempo, por e para indagar a respeito do ser, mostra-se a necessidade de se interrogar um ente em seu ser, justamente este ente que compreende ser, que, enquanto tal, é o que ele é a partir do relacionamento de ser e compreensão de ser com o ser ele mesmo, tomando-se este no sentido da diferença ontológica (o que "é", melhor, vige, vigora, não sendo ente, mas determinando ente enquanto ente), numa palavra, impõe-se a necessidade de interrogar a nós mesmos, enquanto lugar da abertura do círculo da revelabilidade do ente e do 
desvelamento do ser (Dasein). O nosso ser-homem, tomado desde esta referência com a diferença ontológica (transcendência), é o interrogado (das Befragte) no questionamento do ser. A fenomenologia, agora fundada na questão fundamental da verdade do ser (Grundfrage) e não na questão condutora da entidade do ente (Leitfrage), própria da filosofia qua metafísica, se reconfigura a partir da necessidade de se encontrar o modo de exibição (Aufweisungsart) do ser, o qual é essencialmente diverso da descoberta (Entdeckung) do ente. O terceiro momento estrutural da questão é o inquirido (das Erfragte), a saber, o "sentido do ser" (Sinn vom Sein). Em jogo, aqui, porém, está, não propriamente a significação fundamental da multifária significa do ente, mas sim o sentido (Sinn) como o que funda o âmbito do projeto da compreensão do ser, a saber, a verdade do ser, a vigência de sua revelação.

No caminho de pensar de Heidegger, depois, num amadurecimento maior da questão "Ser e Tempo", o interrogado (das Befragte) não é tanto o ser-homem em sua referência de ser com o ser como diferença ontológica (Dasein), mas o ser (Sein) tal como foi experimentado na história da metafísica, ou seja, como entidade do ente. Assim, a investigação da questão (e não do tratado) Ser $e$ Tempo se transforma numa meditação da história do ser: "na pergunta pelo sentido do ser o interrogado é o ser, quer dizer, o ser do ente; aquilo, com vistas a que é interrogado, o inquirido (das Erfragte), é o sentido do ser - o que mais tarde é nomeado como a verdade do ser", como diz Heidegger no Seminário realizado em Zähringen, na seção de 6 de setembro de 1973 (1986, p. 377378).

Fenomenologia é método de penetração e desvelamento da coisa mesma da filosofia: o ser. Ela é "possibilidade de pesquisa originária filosófica", segundo a caracterização que Heidegger aduz em na primeira parte de um texto projetado para a conferência Fenomenologia e Teologia ( $1^{\text {a }}$ parte), de 8 de julho de 1927, cujo título é: "As ciências não filosóficas como positivas e a filosofia como ciência transcendental", presente no volume de conferências (GA 80.1) (2016, p. 179212). Ele diz: "filosofia - como se mostrará -, a ciência do ser - ontologia. E fenomenologia é o método da ontologia, isto é, o esforço pelo procedimento científico da filosofia" (2016, p. 182). Mas, o que é "científico"? O que é ciência? O conceito de ciência, em Heidegger, não é o conceito formado a partir do 
conhecido, mas sim, a partir do conhecer. Partindo do conhecido, temos o conceito lógico e o conceito axiológico. O conceito lógico encara a ciência como um todo de conhecimentos, no sentido de uma concatenação de fundamentação de proposições verdadeiras (validades teoréticas). O conceito axiológico encara a ciência como valor. $O$ que vale como proposições verdadeiras, abriga em si valor. O valor é, neste caso, o da verdade. As realizações de valor são chamadas de "bens". Ciência, como concatenação de fundamentação de proposições dotadas de valor, realiza um valor cultural, é um bem cultural.

Heidegger concede que a ciência pode ser encarada assim, está correta esta posição. No entanto, ela não desvela a essência primordial da ciência. Para se aceder a esta essência primária da ciência é preciso partir do conhecimento não desde o conhecido (sentido noemático), mas sim desde o conhecer (sentido noético). Conhecer é, aqui, um comportamento (Verhaltung) humano. É um modo de ser, de existir, do ser-homem. Por isso, este conceito de ciência é existencial. Aqui a ciência é compreendida como uma livre possibilidade da existência humana. É realização do ser-no-mundo, vale dizer, da transcendência, da liberdade. O conhecer, seja pré-científico, seja científico, tem o caráter de um desvelar (Enthüllen). O desvelar acontece seja como o descobrir (Entdecken) do antes encoberto, no caso dos entes que nós mesmos não somos, os entes intramundanos, seja como o abrir (Erschliessen) do antes fechado, no caso do ente que nós mesmos somos. Conhecer é um livre empenhar-se pelo desvelamento, quer do ente, quer do ser. A liberdade, aqui, não é apenas negativa, um desvencilhar-se dos vencilhos que impedem o desvelamento. A liberdade é também positiva, um livre vincular-se (ein freies Sichbinden) ao que se há de desvelar enquanto tal (an das zu Enthüllende als solches). A liberdade humana, no entanto, se funda na liberdade da verdade do ser. Quer dizer: tanto a liberdade negativa quanto a liberdade positiva do homem se funda na liberdade criativa do ser, de sua verdade, o que mais adiante, em nosso artigo, aparecerá como a "clareira do ser".

Filosofia é o livre empenho da existência humana pelo desvelamento do ser, tomando-se "ser" não como a entidade do ente, ao modo da tradição, mas como a diferença ontológica. No semestre estivo de 1926, nos §§ 3 e 4 de uma preleção sobre Os conceitos fundamentais da filosofia antiga, já aparecia a noção 
capital de "diferença ontológica" (HEIDEGGER, 1993a, p. 5-11). Heidegger dizia ali que a filosofia tem por vocação ser uma ciência crítica. A noção de "crítica" aqui não quer dizer, como usualmente entendemos, a capacidade de desmascarar e censurar o não verdadeiro (o falso em seus vários sentidos: como a mentira, a ilusão, o erro, a inautenticidade). Tem a ver, antes, com o exercício do que evoca o verbo grego "kríno": separar, distinguir, discernir. A questão do ser em Heidegger é crítica no sentido de prestar reconhecimento à diferença entre ente e ser (diferença ontológica). "Tudo aquilo que as ciências descobrem é o ente. As ciências positivas são ciências do ente" (HEIDEGGER, 1993a, p. 6). Para elas, o que está em jogo é o ente e nada mais, como se dirá na preleção $O$ que é metafísica, de 1929, presente em Marcas do caminho (HEIDEGGER, 1996, p. 105). O ser, no sentido da diferença ontológica, di-ferença re-ferente entre ente e entidade (tanto como modo de ser, essência, possibilidade, quanto como fato de ser, existência, realidade efetiva), tem a ver com este "nada" do "nada mais".

Este "nada" é experimentado e se revela ao homem numa disposição fundamental (Grundbefindlicheit), como o advento de uma entoação, afinação ou sintonia (Stimmung) da existência desde o fundo do seu ânimo, do coração (Gemüt). Não está em jogo, aqui, um captar do todo do ente, mas sim um "encontrar-se em meio ao ente no todo" (Sichbefindeninmitten des Seienden im Ganzen) (HEIDEGGER, 1996, p. 110). Trata-se de uma intuição originária, que, contudo, não é de conteúdo reflexivo. Antecede a toda a reflexão (é pré-reflexiva). É certo que, para o homem discorrer a respeito dela, ela precisa se dar na reflexão da consciência. Mas, embora se dê na reflexão, não se dá originariamente como reflexão (LEÃO, 2013, p. 33). Esta disposição fundamental é a angústia. 0 § 40 de Ser e Tempo expõe a angústia como uma privilegiada abertura (Erschlossenheit) da presença (Dasein) (HEIDEGGER, 1993b, p. 184-191). Ela não é o temor, mas o que torna o temor possível. Ela não é o temor diante de algo intramundano (o temido que se revela como o ameaçador). Nela, o intramundano, isto é, o que nos vem algo encontro "dentro" do mundo, se nos torna insignificante. O insólito e sinistro que se sente na angústia não provém de algo, de algum lugar. Ele já está "aí" e sua proximidade é tão grande que nos aperta a garganta e nos tira o fôlego. Ele revela o nosso próprio ser-no-mundo, o que nos é mais familiar, como o insólito, como o estranho. A angústia revela no nosso âmago a existência como 
um poder-ser. Ela mostra na nossa presença (Dasein) o ser para o poder-ser, o ser livre para a liberdade de escolher-se-a-si-mesmo. O ser que aparece no ser livre, que faz entrar em vertigem o nosso mundo "familiar", não é nenhum isto ou aquilo, não é nenhum ente que não somos nem mesmo o ente que somos, é... nada... nada de ente. Nisso, se dá a notar o ser como diferente, como outro do ente. Em virtude de nosso arraigamento no ente, porém, o captamos sob a perspectiva da negatividade transcendente, como "nada".

Em outro texto, preparado para uma conferência, ministrada em 4 de dezembro de 1926, intitulado "Conceito e desenvolvimento da pesquisa fenomenológica" (Begriff und Entwicklung der phänomenologischen Forschung) Heidegger (2016, p. 159-178) diz que fenomenologia não é um sistema da filosofia; não é uma corrente ou endereço real da filosofia contemporânea; também não é uma visão de mundo (Weltanschauung). É, antes, a luta da filosofia por si mesma, os esforços da filosofia por vir a ser ciência (Wissenschaft), isto é, o vigor e a vigência de um saber (Wissen), que consiste em ver - saber por ter-visto, possibilidade de realização e de resguardo do desencobrimento (descoberta do ente que não somos, abertura do ente que somos; revelabilidade do ente, desvelamento do ser). Fenomenologia é a realização do empenho que a filosofia tem, desde o seu começo, de conseguir ser originária.

O que a filosofia tem de perene é este empenho de concentração no originário. As doutrinas, as teses, os sistemas, são apenas rastros que o movimento de busca do originário deixam para trás. A comunicação viva entre os filósofos que se dá ao longo dos tempos na e como tradição se dá a partir daí. É para aí que eles convergem. É a partir daí que eles divergem. Filosofia é o pensamento que busca a originariedade do perguntar. E fenomenologia é, antes de tudo, tomar a sério o rigor e a radicalidade deste questionar. Fenomenologia é a retomada do propósito: Filosofia como ciência de rigor!, para usar o título do artigo de Husserl na revista Lógos. Onde e quando a filosofia assume com radicalidade e de modo bem sucedido esta "pegada", esta "vibe", esta vibração, ali ela está sendo fenomenológica. Não interessa se este momento fenomenológico se exibe em Platão ou em Aristóteles, em Kant ou em Hegel, ou no próprio Husserl, que não é o primeiro fenomenólogo da história, ou em Heidegger, que, esperamos, não seja o último. 
A originalidade da fenomenologia, assim, não está na sua novidade. Não é algo novo, que, mal irrompeu, já envelhece. Não é e não pode ser moda. A originalidade da fenomenologia está em ser antiga, arcaica, originária (HEIDEGGER, 2016, p. 162). Consiste em retomar com rigor e radicalidade o que a filosofia tem de mais antigo, de mais arcaico, mas que permanece sempre inveterado, jovial: a questão do ser.

A questão do ser se desdobra como a pergunta pela essência da verdade e pela verdade do essência, melhor, pela verdade do ser. A questão do ser enquanto questão da verdade torna-se a questão fundamental (HEIDEGGER, 1984, p. 27-190). A partir da questão do sentido do ser, melhor, da questão da verdade do ser, questão fundamental (Grundfrage), e não só a partir da questão do ser no sentido da pergunta pela entidade do ente, questão condutora (Leitfrage) da tradição, a fenomenologia ganha uma nova configuração de ciência de rigor. Ela se põe não só como ciência, no sentido de uma ontologia universal (mathesis universalis), no sentido de uma exploração sistemática da consciência intencional em seu a priori e em sua função constituinte de todo o sentido de ser; ela se põe como ciência crítica.

As ciências positivas (que partem de determinadas regiões do ente já postas, já desveladas, para, em seguida, desvelá-las numa tematização que é objetivação), são críticas em relação ao que elas pesquisam na positividade ôntica. Mas são ingênuas do ponto de vista transcendental. A filosofia fenomenológica quer ser ciência transcendentalmente crítica. Ela trabalha com a distinção entre positividade (do mundo dos fatos) e transcendentalidade (da consciência intencional pura). Mas, em Heidegger, esta criticidade da filosofia fenomenológica precisa dar um passo a mais. Ela precisa se tornar crítica no sentido de levar em consideração a diferença ontológica. Toda a tradição filosófica, toda a filosofia qua metafísica, a supõe, porém, não a questiona. A filosofia em sua tradição, de Platão a Husserl, embora se funde sobre a diferença ontológica, caminha no seu esquecimento. Heidegger, no $\S 2$ de Ser e Tempo, no entanto, se propõe questionar isto que, na tradição, permanece inquestionado: "O questionado da questão do ser a ser elaborada é o ser, o que determina o ente como ente, como o ente já é sempre compreendido, em qualquer discussão que seja. O ser dos entes não "é" em si mesmo um outro ente" (HEIDEGGER, 1993b, p. 6). 
Heidegger fala de disciplinas positivas e da disciplina crítica. Ele esclarece a diferença entre positivo e transcendental, crítico, numa anotação "telegráfica", concisa, da conferência já mencionada "Conceito e desenvolvimento da fenomenologia":

crítico: isto é, consumar (Vollziehen) diferença ontológica. Desperto para o ser e só assim propriamente para 0 ente. Positivo: \{desperto\} só para este $\{0$ ente\}, separando do ser. [Vigília] transcendental, que esta vigília ultrapassa a positiva; não para um atrás-de, mas para um antes-de. Que, na verdade, já está aí, mas somente em sonho; não para longe do ente, desde o ente (vom Seienden), que jaz antes do ente. Antes - de onde - a transcendência mesma - é tema. Transcendência = intenção em sentido comum, mundo diurno (Tagwelt) (2016, p. 165-166).

Fenomenologia é, assim, uma realização, um levar a cabo, uma consumação da diferença ontológica. É abrir acesso a ela. Deixá-la aparecer como tal. O homem já vive sempre no entremeio da diferença ontológica (de ente e ser). É a partir deste entremeio que ele faz a experiência ontológica, melhor, pré-ontológica (pois não temática, não explícita, mas operativa), que está na raiz da arte, do mito, da religiosidade, etc. É a partir deste entremeio que o homem vive o seu mundo cotidiano, o seu mundo diurno, em que ele, embora desperto para os entes em sua positividade, dorme para o ser. Filosofia fenomenológica é despertar para o ser. A transcendência ontológica, diversa da transcendência psicológica (o que está além da consciência) e da transcendência teológica (o que, como o divino, o absoluto, o incondicionado, o necessário, em oposição ao contingente, tudo excede), não diz uma ultrapassagem para além. Diz um retorno para aquém. A filosofia fenomenológica conduz-nos para aí, onde já sempre estamos. Nos reporta ao mais próximo, cuja proximidade é tanta que já sempre ultrapassamos, nos "passando batido". Nos conduz ao ser-no-mundo e sua transcendência. Reportanos à transcendência como a anterioridade de um "medium", de um elemento, que nos dispõe e nos sustenta e nos permeia e perpassa e, ao mesmo tempo, nos ultrapassa. Nela está em jogo uma "redução transcendental", no sentido de uma recondução a esta anterioridade do "medium" (meio elemento, o imediato). Manter-se desperto na vigília desse "medium": eis a filosofia fenomenológica como realização de uma possibilidade de ser, de existir.

Mais do que de uma transcendentalidade da consciência, em jogo está a transcendentalidade do Dasein: do já ter-se aberto do círculo do interesse, do 
"estar aí" para o ser, para o acontecer da verdade ôntica (revelabilidade do ente) e ontológica (desvelamento do ser qua diferença). O círculo da verdade ônticoontológica, anterior à verdade predicativa, se abre a cada vez numa disposição fundamental (temor, angústia, tédio, mas também jovialidade, serenidade, etc.). Ela se abre também na compreensão (Verstehen). A compreensão do ser é um "Grundfaktum", um fato fundamental, cuja facticidade não é a da ocorrência dos feitos concernentes a coisas, mas sim a da existência mesma (HEIDEGGER, 2016, p. 169). A compreensão do ser já sempre se irrompeu em nossos discursos cotidianos, no simples dizer "é". O ser mesmo, nunca encontrável como um ente entre outros entes, já sempre vige aí em todo o compreender (HEIDEGGER, 2016, p. 170).

Quando falamos de "ser" não conseguimos representar nada, nenhum ente, coisa nenhuma. É como se tentássemos agarrar o vazio. Neste sentido, ser e nada são o mesmo, conforme lemos no mencionado texto preparado para a primeira parte de Fenomenologia e Teologia (HEIDEGGER, 2016, p. 199). Filosofia é ciência do ser - filosofia é ciência do nada. Neste sentido, ser parece algo incompreensível. E, no entanto, estamos sempre compreendendo tudo desde ser e na perspectiva de ser. Estamos, cotidianamente, dizendo "é". Compreendemos o "é", mas não conseguimos conceituá-lo. A nossa compreensão do ser é um fato fundamental. E, no entanto, não é uma compreensão conceitual. Em todo o nosso existir, em todo o nosso ser-no-mundo, em todo o nosso relacionamento com o ente, estamos sendo carregados pela compreensão do ser. Esta compreensão já sempre vige, é anterior (estruturalmente) a todo o nosso comportamento para com o ente, também para com o nosso conhecimento do ente (descoberta, abertura). Este anterior, em sentido transcendental, é o tema da ontologia (HEIDEGGER, 2016, p. 200). A fenomenologia é o retorno da positividade do ente à transcendentalidade do ser.

Filosofia fenomenológica é ciência crítica. Isto é dito por Heidegger tendo em mira a significação do verbo grego "kríno", separar (scheiden), diferenciar (unterscheiden). Decerto, as ciências positivas são críticas, na medida em que se tornam competentes em separar e diferenciar ente e ente. Criticidade aqui significa um modo rigoroso de determinar os entes. Todo determinar é diferenciar. Elas são críticas também segundo a significação usual que damos a esta palavra, 
isto é, de não aceitar de boa-fé qualquer afirmação, negação, posição. Isto quer dizer: são críticas por seguirem critérios de procedimentos metódicos, que põem à prova, examinam, as posições e crenças humanas, buscando determinar o que está em causa nas suas pesquisas. Criticidade quer dizer aqui objetividade, no sentido de se ater à coisa que está em questão (Sache). Entretanto, as ciências positivas são transcendentalmente ingênuas.

A filosofia fenomenológica é crítica na medida em que ela diferencia o positivo e o transcendental, o ôntico e o ontológico. O positivo, o ôntico, o ente e - que lhe concerne, é encontrável no que já está posto, desvelado. 0 transcendental, o ontológico, o ser e o que lhe concerne, não. Ser já sempre vige "aí" na compreensão de ser que rege todo o nosso relacionamento com o ente as categorias das ciências positivas atestam isso, nossa compreensão préontológica cotidiana também. Mas ser nunca se deixa encontrar como ente. Carece de um modo de acesso próprio. A fenomenologia é o método de acesso ao ser qual fenômeno originário. Ela é o método da ontologia, que é o cerne da filosofia.

Categorias não dizem entes e nem momentos concernentes ao entes positivamente dados. Categoria diz algo como um modo de chamar em causa os modos de ser do ente. Nelas, a cada vez, vem à compreensão uma constituição de ser (Seinsverfassung). Filosofia fenomenológica não é conhecimento de entes não é nenhuma teoria ôntica, positiva. É elucidação de constituições ontológicas, é exercício de pensamento, de meditação. Fenomenologia não é tornar noto características dos entes, mas sim constituições de ser. Por isso, para Heidegger, em Husserl o decisivo está na descoberta da "intuição categorial".

Numa preleção de Marburgo de 1925, intitulada "Prolegômenos à história do conceito de tempo", em sua parte preparatória, Heidegger procura expor o sentido e a tarefa da pesquisa fenomenológica (1994, p. 13-122). Ele descreve o surgimento e a primeira irrupção da pesquisa fenomenológica, descrevendo como aparece o trabalho de Husserl, sob o fundo da situação filosófica da segunda metade do século XIX, especialmente no tocante à relação entre a filosofia e as ciências (positivas). Depois, ele fala das descobertas fundamentais dessa pesquisa: a intencionalidade, a intuição categorial e o sentido originário do apriori. Procura elucidar o sentido da máxima "à coisas mesmas" e discute a autocompreensão da fenomenologia como descrição analítica da intencionalidade no seu apriori. Como 
faz no $\S 7$ de Ser e Tempo, ele procura, então, realizar uma aclaração (Klärung) do nome "fenomenologia" a partir de seus componentes etimológicos: "phainómenon" e "lógos".

A "pars destruens" da crítica de Heidegger visa preparar a "pars construens", isto é, o alcance da pesquisa fenomenológica como "fenomenologia fundada na questão do ser" (Seinsfrage). Heidegger atenta para a necessidade de uma meditação radical na pesquisa fenomenológica e desde ela para fora e para além da sua primeira formação (nomeadamente, no trabalho de Husserl e Scheler) (1994, p.123-182). O movimento negativo da crítica se volta para a elaboração do campo temático: a determinação fundamental da intencionalidade e a elaboração da consciência pura enquanto região de ser própria. A crítica imanente se exerce discutindo criticamente as quatro determinações da consciência pura: 0 ser imanente, o ser absoluto (no sentido de absoluta datidade), o ser absolutamente dado no sentido de "nulla re indiget ad existendum" e o ser puro. Por fim, Heidegger indica duas omissões decisivas na pesquisa fenomenológica de até então: a omissão da pergunta pelo ser do intencional enquanto o campo temático da pesquisa fenomenológica e a omissão da pergunta pelo sentido do ser mesmo conjuntamente com a pergunta pelo ser do homem. Ora, o que Ser e Tempo procura positivamente elaborar é justamente tal pergunta pelo ser mesmo em conexão com a pergunta pelo ser do homem, compreendido não a partir da subjetividade, isto é, da relação sujeito-objeto, mas sim a partir do "Dasein", isto é, do relacionamento entre a essencialização do homem, tomada como o lugar de que carece o ser para a sua abertura, e o ser mesmo (diferença ontológica, nada).

A "coisa mesma", isto é, o que está em questão, como tarefa da filosofia fenomenológica é, em Heidegger, o sentido ou a verdade do ser. A avio da investigação fenomenológica dele em direção à "abertura das 'coisas mesmas", para mencionar a nota feita por Heidegger em reconhecimento à contribuição de Husserl em seu caminho de pensamento (1993b, p. 38) se deu, certamente, graças ao seu encontro com as Investigações Lógicas. O sexto capítulo da sexta das Investigações Lógicas era para Heidegger o foco, isto é, o ponto de combustão (Brennpunkt) do pensar husserliano. Com outras palavras, o tratamento da "intuição categorial" era o ponto em que se acendia o "fogo" da questão do ser no pensamento de Husserl. $O$ acesso à questão do ser, desde a 
fenomenologia de Husserl, se dava a partir dali (HEIDEGGER, 1986, p. 372). Mas, qual a importância da descoberta da intuição categorial? Para Heidegger, conforme se lê nos Prolegômenos já mencionados, pela primeira vez se ganhava, com ela, "um caminho concreto de uma pesquisa demonstradora (ausweisende) e autêntica das categorias" (1994, p. 97-98), tema fundamental da ontologia.

Com a intuição categorial, a fenomenologia husserliana abria um caminho mais promissor do que o de Aristóteles e o de Kant na exposição das categorias. A tradição filosófica tinha entendido as categorias como determinações últimas ("gêneros supremos"), irredutíveis umas às outras, do ente como tal e como um todo. Só podiam ser transcendidas na direção do ser e de suas determinações universais, cuja universalidade, no entanto, não era de cunho genérico, isto é, dada ao modo dos gêneros e das espécies (os transcendentais). O ser era o transcendental por antonomásia. A meta-física, "scientia transcendens". Em Aristóteles, as categorias significavam os modos fundamentais de ser do ente, tornados acessíveis a partir das formas fundamentais de enunciados sobre o ente enquanto ente. Em Kant, as categorias eram tomadas como conceitos apriori do entendimento, funções fundamentais na ordenação do material da experiência sensível; não bem modos fundamentais do ente, mas antes modos de constituição para a consciência dos objetos em sua objetualidade.

Com a descoberta da intuição categorial abre-se um caminho mais promissor, na medida em que se descobrem atos (de síntese e de ideação) em que consistências ideais (ideale Bestände) neles se mostram (HEIDEGGER, 1994, p. 85-99). Os modos fundamentais do ente enquanto ente, melhor, as determinações últimas do ser, de uma universalidade não genérica, mas oniabrangente, transcendental, não são meros produtos fictos da consciência, de seus atos, nem meras funções do pensamento, do sujeito. Os atos categoriais e o que neles se mostra têm o caráter de presentação. $E$ isso que se presenta é que oferece o solo fenomenal para a elaboração da estrutura das categorias, quer dizer, para o ressaltar das estruturas das consistências ideais. Os atos de ideação presentam consistências ideais. $O$ ideal como tal, respectivamente, o categorial tem sua própria consistência e sua própria objetualidade (embora não a consistência do que é real). A objetividade se amplia e abrange o domínio do ontológico. O a priori não é só um caráter do da esfera subjetiva. É também da 
esfera objetiva. Não há apenas o apriori formal, mas há também o apriori material. Depois, o apriori abrange tanto o real e o ideal. Na fenomenologia, "apriori" não é um título do comportamento (Verhalten), mas antes um título do ser (Titel des Seins) (HEIDEGGER, 1994, p. 101). O "apriori" é primeiro não na ordem do conhecer, nem numa ordem ôntica, do surgimento do ente a partir do ente. $O$ "aprior" é primeiro no sentido ontológico, isto é, no sentido de um "caráter da sequência estrutural no ser do ente, na estrutura de ser do ser" (HEIDEGGER, 1994, p. 102).

Para Heidegger, o grande préstimo que a fenomenologia husserliana tinha realizado para a questão do sentido do ser era mostrar que esta questão tinha um solo:

\begin{abstract}
Para que a questão do sentido do ser pudesse ser simpliciter desdobrada, era preciso que o ser se desse, para junto dele se inquirir seu sentido. O préstimo de Husserl consistiu justamente no visualizar presencializante (Vergegenwärtigung) do ser, que está vigente (anwesend) na categoria. Por este préstimo, continua Heidegger (sic), eu tinha finalmente um chão: "ser" não é um mero conceito, uma pura abstração, que surgiu neste caminho. $O$ ponto, entretanto, para além do qual Husserl vai, é o seguinte: depois que ele ganhou o ser por assim dizer enquanto doado (als Gegebenes), ele não pergunta adiante, contudo, por ele. A pergunta "O que diz ser?" ele não desdobra. Para Husserl não havia sequer a sombra de uma possível questão, porque para ele era compreensível por si mesmo que "ser" significava ser-objeto (Gegenstand-sein) (HEIDEGGER, 1986, p. 378).
\end{abstract}

Para Heidegger, porém, a objetualidade (Gegenständlichkeit) era apenas um modo da presença (Anwesenheit), a saber, era o ser-presente (Anwesendsein) na dimensão ou no "espaço" da subjetividade. Para Husserl, a "coisa mesma", isto é, a tarefa da fenomenologia, o que nela estava em questão, em causa, era a subjetividade transcendental, como fonte absoluta da estruturação de todo o sentido e validade de ser, sobre a qual se fundava, ao modo de constituição, a objetualidade de todos os objetos, isto é, o ser do ente. Fenomenologia era, assim, a ciência universal da constituição dos objetos em sua objetualidade (ente em seu ser). Fenomenologia era ontologia científica rigorosa. Nestes sentido, é fundamental, nos parece, a exposição que Husserl faz da fenomenologia na terceira parte da quarta versão preparada para o verbete "Fenomenologia", da Enciclopédia Britânica, em apêndice no volume IX das Husserliana (Cf. HUSSERL, 1968, p. 296-301). 
O princípio dos princípios exposto no parágrafo 24 de "Ideias I" (HUSSERL, 1993, p. 43-44) é um princípio operativo da pesquisa fenomenológica. Trata-se do princípio de evidência. É o princípio de voltar às coisas mesmas, isto é, de desenvolver as intuições para chegar à evidência do que os termos intencionam, o qual recomenda a experiência de receber, numa visão direta, a coisa mesma. Temse como guia o enunciado segundo o qual "toda intuição originariamente doadora é uma fonte justa do conhecimento; que tudo aquilo que se nos oferece originariamente numa 'intuição' (por assim dizer em sua realidade efetiva, em carne e osso), há de ser tomado simplesmente como aquilo que se mostra, mas também só nos limites em que se dá ali". Este princípio, enfim, abre o acesso para a autoevidência da auto-presença da consciência, no sentido da subjetividade transcendental, fonte absoluta, enquanto absoluta datidade, da constituição de todos os objetos em sua objetualidade.

Não é assim que método e tema sejam duas realidades extrínsecas. Método (procedimento) e tema (questão, coisa mesma, o que está em causa) não estão um para o outro simplesmente como chave e fechadura, para usar uma analogia de Heidegger em $O$ fim da filosofia e a tarefa do pensamento (1988, p. 70). Método e tema se identificam na dinâmica da investigação. $O$ método da pesquisa fenomenológica transcendental, a começar pelo princípio dos princípios de sua operatividade, pesquisa esta compreendida como retorno à consciência, no sentido da subjetividade transcendental, já pressupõe esta como a "coisa mesma" da filosofia. É o pressuposto da filosofia transcendental moderna - quer se trate da subjetividade da consciência de um "ego cogito" que se dá na autoevidência de uma auto-presença, na absoluta certeza de si mesmo, como base de todos os atos de representação e de pensamento (Descartes), quer se trate da subjetividade de um sujeito finito (Kant), quer se trate da subjetividade do sujeito absoluto (Hegel). A subjetividade como condição transcendental dos objetos em sua objetualidade aparece, na filosofia moderna, como o fundo subjacente a todo objeto e objetualidade, é o que torna possível todo o ens enquanto obiectum.

Assim, a relação entre a fenomenologia de Husserl e a de Heidegger não pode ser explicada como uma identidade de método (fenomenologia) e uma diferença de tema, ou seja, consciência intencional em Husserl, Dasein em Heidegger. Não é assim que o método fenomenológico em Husserl e em 
Heidegger é um procedimento para se chegar a conhecer, ali (em Husserl), os feitos e atos da consciência, aqui (em Heidegger), as estruturas existenciais do Dasein.

A constituição intencional dos feitos e dos atos da consciência não perfaz o que há de fenomenológico na fenomenologia de Husserl e sim o procedimento específico com que se descobre e encontra a constituição intencional da consciência. Do mesmo modo, o que há de propriamente fenomenológico na fenomenologia da presença [Dasein] não está nas estruturas existenciais que formam o modo de ser da pre-sença, a existência. O fenomenológico da ontologia fundamental é o método, o modo de liberar, die Freilegung, as estruturas existenciais da dinâmica de totalização da temporalidade originária (LEÃO, 2013, p. 30).

O decisivo na fenomenologia não está no "quê coisal" (das sachhaltige Was) dos objetos da pesquisa fenomenológica, mas está, antes, no "como" (Wie) desta mesma (HEIDEGGER, 1993b, p. 27). O essencial da fenomenologia está no procedimento (Verfahren), isto é, no modo de ir adiante, abrindo caminho na questão. O título "fenomenologia" se torna patente na máxima "às coisas mesmas!", que, negativamente, proíbe fazer uso de construções de conhecimento não assentadas, de achados casuais, de conceitos não demonstrados, de questões aparentes, de teorias estabelecidas, de filosofias já constituídas, de ontologias legadas historicamente etc.; e que, positivamente, recomenda ater-se ao princípio da evidência, ao que a intuição oferece, à experiência intuitiva da verdade, conforme os "Prolegômenos à história do conceito de tempo" (HEIDEGGER, 1994, p. 104).

No $§ 7$ de Ser e Tempo, Heidegger mostra-se de acordo com esta máxima. Fenomenologia é "conceito de método" (Methodenbegriff) (1993b, p. 27). Fenomenologia não é uma teoria do real no sentido das ciências; não é um modelo explicativo produzido pelo conhecimento ôntico, positivo, objetivo; não é também uma doutrina de uma visão de mundo. Fenomenologia é atividade do pensar filosófico. É modo de abrir caminho no questionamento das questões e dos problemas filosóficos. Decerto, o questionamento filosófico questiona alguma coisa. Tem objeto temático. Este objeto temático é o ser do ente. Fenomenologia e ontologia não estão uma ao lada da outra, paralelamente. Ontologia, tomada não como disciplina filosófica, mas sim como a questão fundamental da filosofia, se desdobra como fenomenologia. "O ressaltar do ser do ente e a explicação do 
ser mesmo é a tarefa da ontologia" (HEIDEGGER, 1993b, p. 27). Fenomenologia é o modo de tratar desta investigação, para que ela cumpra sua tarefa.

Em Husserl, a fenomenologia cunha a filosofia como filosofia fenomenológica, que se propõe como "ciência universal" (mathesis universalis) e, ao mesmo tempo, como "ciência fundamental" (Grundwissenschaft). A "pura" fenomenologia é "fenomenologia transcendental". A coisa mesma da filosofia (aquilo que nela está em questão, em causa) se mostra como a "subjetividade transcendental". Como a filosofia fenomenológica se põe como crítica da razão teorética, prática e axiológica, a subjetividade em questão é a subjetividade do sujeito que conhece, que age e que põe valores. Ora, nisso, a filosofia fenomenológica segue na esteira da tradição ocidental, que procura iluminar o ser a partir do pensar(do "noeín", do "lógos", da "ratio", da "Vernunft'), e, mais precisamente, da tradição de pensamento moderno, que procura aclarar o ser (sein) do ente desde a consciência (Bewusst-sein). Nesta fenomenologia, o "lógos" do fenômeno só aparece graças à mediação da subjetividade transcendental. A redução transcendental é, assim, o método da "ciência universal" da constituição do ser do ente, afirma Heidegger em $O$ fim da filosofia e a tarefa do pensamento (1988, p. 70).

Ora, desde Descartes até Hegel, passando por Kant, a consciência (Bewusstsein) é aquela dimensão originária, a partir da qual se dá a estruturação do horizonte da objetualidade dos objetos (do ser do ente). Mas, através da fenomenologia, a subjetividade transcendental alcança uma "determinidade mais originária e universal", lemos em Meu caminho na fenomenologia (HEIDEGGER, 1988, p.84). Redução transcendental e eidética, bem como constituição permitem tal alcance:

\footnotetext{
A fenomenologia manteve "vivências de consciência" como seu domínio temático, mas agora na perscrutação sistematicamente projetada e assegurada da estrutura dos atos de vivência em unidade com a perscrutação dos objetos experimentados nos atos em termos de sua objetualidade (HEIDEGGER, 1988, p.84).
}

As vivências, no entanto, não são o foco, nem o eu, que nelas vive, mas a própria vida fática, dito de outro modo, a existência, modo de ser ou essência do "Dasein". Vivência é chance de abrir a região fenomenal da vida. Vivência não é coisa. Vivência é comportamento da vida (por e para ser comportamento do 
vivente). A vivência não está fundamentalmente referida ao eu. $\mathrm{O}$ eu é que, pela vivência, está enraizado no acontecer da vida como tal. Vivência não é processo, mas evento (Ereignis). O eu ressoa no acontecer da vida, no evento da vivência, e, nessa ressonância, mundo se faz mundo. "Só no ressoar-com de cada eu próprio é que se vivencia um algo mundano-circunstante, é que acontece mundo, e onde e quando acontece mundo para mim, eu estou de alguma maneira bem ali, juntinho", lemos em Para a determinação da filosofia, no texto da preleção do "semestre de indigência de guerra", de 1919, intitulada $A$ ideia da filosofia e o problema da visão de mundo (HEIDEGGER, 1987, p. 73).Vida fática, existência, Dasein - eis o novo campo temático da nova fenomenologia, fundada sobre a questão do ser.

\section{A coisa mesma da fenomenologia como a clareira do ser.}

No caminho de pensamento de Heidegger, a fenomenologia se torna "a fenomenologia fundada na questão do ser" (1994, p. 183). Fenomenologia é o método da filosofia qua ontologia. Fenomenologia é modo de realizar a pesquisa, melhor, a sondagem (Forschung = scrutatio) do ser. "O princípio da pesquisa é o princípio da obtenção do campo coisal, o princípio da criação da prospectiva, a partir da qual a cousa em causa (Sache) é sondada, e o princípio da elaboração do modo de tratamento, do método" (1994, p. 103, grifos do autor). O princípio da pesquisa não é, pois, uma tese, um dogma, mas é "aquilo, a partir de que ela se orienta continuamente em sua realização, o que, enquanto fio condutor, conduz continuamente seus próprios passos" (1994, p. 104).

O princípio da pesquisa é, pois, o que a deixa começar, a erige e a rege e a leva à consumação. É o que conduz a pesquisa, melhor, a sondagem, enquanto busca, questionamento, investigação. "Um princípio, enquanto determina a realização de uma possibilidade da existência da presença (Dasein), chama-se também uma máxima" (1994, p. 104, grifo do autor). Buscar, questionar, investigar, sondar, são atos humanos em seu engajamento pelo ver, isto é, pelo descobrir do ente e pelo desvelar do ser. Fenomenologia é tomar a decisão de 
ver, de alcançar um real, efetivo ver (HEIDEGGER, 2018, p. 37). Ela diz a possibilidade do pensar, de se realizar como o "simples ver" (schlichtes Sehen) do ser. O simples pode ser fácil a partir da coisa mesma. Mas não a partir de nós mesmos. A partir de nós, o simples é sempre o mais difícil. Só a partir da coisa mesma é que o simples é fácil. Fenomenologia é possibilidade de a existência humana se realizar no modo do simples ver da coisa mesma. Por isso, a máxima ou princípio da fenomenologia é: "às coisas mesmas!". Esta máxima traz uma dupla exigência positiva: a de trabalhar na sondagem do campo coisal de maneira a, sempre de novo, demonstrar, tornar noto indicando (ausweisen) o solo fenomenal; e, de maneira ainda mais fundamental, obter e assegurar este solo fenomenal do campo coisal a ser sondado. O decisivo, na fenomenologia, é a liberação (Freilegung) do campo. "As coisas mesmas", portanto, são o solo fenomenal do campo coisal, isto é, do campo que se abre, que se libera, como concernente à "coisa mesma" (Sache selbst) da sondagem, ou seja, que concerne ao que nela está em causa, em questão, em discussão, enfim, ao que interessa $($ Sache $=$ cousa $=$ causa $)$.

Com a irrupção da questão fundamental do sentido do ser, portanto, a fenomenologia mantém o seu princípio-máxima de ir "às coisas mesmas" (zu den Sachen selbst), mas, agora, surge uma contenda em torno à "coisa" (Sache) do pensar, isto é sua tarefa, dito de outro modo, em torno à sua "causa originária" (Ur-sache), cujo contencioso se anuncia na pergunta:

a partir de que e como se determina, o que segundo o princípio
da fenomenologia enquanto 'a coisa mesma' (die Sache selbst) há
que ser experimentado? É a consciência e suas objetualidade, ou
é o ser do ente em seu ser desencoberto (Unverborgenheit) e
encobrimento (Verbergung)? (HEIDEGGER, 1988, p. 87).

A primeira alternativa é o caminho da fenomenologia em Husserl, a segunda, em Heidegger.

Em sua primeira configuração, em Husserl, seguindo o fio condutor da questão da entidade do ente, tomada modernamente como objetualidade (Gegenständlichkeit) do objeto, a fenomenologia se realiza como sondagem sistemática da consciência intencional, seu campo coisal, e a liberação do solo fenomenal se cumpre como descrição analítica da intencionalidade em seu a priori. 
A coisa mesma é, aqui, a subjetividade transcendental como fonte absoluta da constituição de todo o sentido de ser e de toda a validade de ser dos objetos. A fenomenologia é a sondagem da subjetividade transcendental como constituinte de todo o sentido de ser. Ela é o método da "mathesis universalis" da constituição do ser do ente, dito de outro modo, da constituição da objetualidade do objeto.

Em sua segunda configuração, em Heidegger, seguindo o fio condutor da questão fundamental do sentido do ser, isto é, da possibilitação da abertura do âmbito do projeto da compreensão do ser, a coisa mesma, com outras palavras, o inter-esse, a causa, o contencioso do pensamento, passa a ser, portanto, o ser do ente em seu ser desencoberto e em seu encobrimento. O solo fenomenal, portanto, já não é a consciência intencional em seu a priori, mas o círculo da verdade ôntica, isto é, da revelabilidade (Offenbarkeit) do ente, de seu possível ser descoberto (se se trata do ente que não somos, mas que nos vem ao encontro como ente intramundano) e de seu possível ser aberto (se trata do ente que nós mesmos somos, enquanto ser-no-mundo), círculo este que é também da verdade ontológica, isto é, do ser-desvelado (Enthülltetheit) do ser. "Só o desvelamento do ser possibilita a revelabilidade do ente" (HEIDEGGER, 1996, p. 131, grifos do autor). Não se dá verdade do juízo ou do enunciado sem a verdade pré-judicativa e pré-predicativa, a verdade manifestativa, que é tanto verdade ôntica (revelabilidade do ente) quanto verdade ontológica (desvelamento do ser). A verdade manifestativa é condição de possibilidade da verdade predicativa ou judicativa; e, nela, a verdade ontológica é condição de possibilidade da verdade ôntica. A verdade ontológica é, assim, a essência do fundamento.

Em Husserl, o fenômeno da objetualidade do objeto só aparece graças à mediação da consciência intencional em sua função constituinte. É graças a esta mediação que o fenômeno ganha um "lógos", isto é, um modo de se deixar interpelar, um modo de se deixar chamar em causa, uma articulação de sentido (abertura e encaminhamento de inteligibilidade). É graças à mediação da consciência intencional em seu a priori, da subjetividade transcendental assim tomada, que o fenômeno passa a ser fenomeno-logia, isto é, reunidor de sentido de ser. A fenomenologia do fenômeno - como ele, no aparecer e desaparecer de sua vigência recolhe e acolhe sentido, no jogo de ser e não ser, de identidade e 
diferença - é liberada, pois, pela consciência intencional em seu a priori e em sua função constituinte. Por isso, o fenômeno originário, puro, absoluto, não é a objetualidade do objeto, mas a própria consciência intencional, sua vida. A fenomenalidade da consciência intencional em seu a priori e em sua função constituinte é a coisa mesma (Sache selbst) da fenomenologia em Husserl. Fenomenalidade quer dizer: o caráter de ser aparecente. A consciência é autopresença e auto-evidência, que media a presentação, apresentação e representação de todo outro fenômeno, constituído como objeto. Por e para representar, a consciência precisa ela mesma estar presente, vir à presença, aparecer, mostrar-se, estar aberta, manifesta, patente (offenbar), em seu desencobrimento (Entbergung), respectivamente, em seu ser-desencoberto (Unverborgenheit). É em seu lume, ou seja, na luz da sua fenomenalidade, que todo o fenômeno objetivo se fenomenaliza.

Heidegger percebeu que a consciência mesma, em sua fenomenalidade, trazia este caráter de ser desencoberto e de desencobrimento. A originariedade da consciência se apoia na originariedade de um fenômeno ainda mais primordial: o da "alétheia", isto é, do ser-desencoberto e do desencobrimento.

O que se realiza para a fenomenologia dos atos de consciência
como o atestar-se a si mesmo (sich selbst Bekunden) dos
fenômenos, é pensado de modo mais originário ainda por
Aristóteles e no todo do pensar e da presença (Dasein) dos
gregos como alétheia, como o ser-desencoberto do vigente
(Unverborgenheit des Anwesenden), de seu desencobrimento
(Entbergung). O que as investigações fenomenológicas tinham de
modo novo encontrado como o suporte que carrega (die
tragende Haltung) o pensar, se demonstra como o traço
fundamental do pensar grego, quiçá da filosofia como tal
(HEIDEGGER, 1988, p. 87).

$\mathrm{Na}$ fenomenalidade da consciência (Bewusstsein) enquanto auto-presença e auto-evidência em que se dá a o atestar-se a si mesmos dos fenômenos pode-se cointuir o dar-se do ser (Bewusstsein). No lume (/umen) da consciência, em que os entes se manifestam como sabidos, vige a luz fontal (lux) do ser. Na verdade ôntica da consciência, na sua revelabilidade (Offenbarkeit), vigora, voga, a verdade ontológica, isto é, o ser-desvelado (Enthülltetheit) do ser. O ser-desvelado do ser é, pois, "dimensão" mais originária que a da consciência. É a dimensão do imediato. Não há, aqui, um intermediário. O imediato é o fundamento da mediação 
(ROMBACH, 1981, p. 66). É a dimensão do aberto (das Offene), ou melhor, da aberta, da clareira (Lichtung). Assim, a questão Ser e Tempo não é um retrocesso da transcendentalidade para a positividade, uma recaída na antropologia. $O$ aparecente da consciência, sua luminosidade, sua fenomenalidade, pressupõe o esplendor do ser. $\mathrm{O}$ aberto em que se abre a dimensão da liberdade da verdade do ser é mais radicalmente transcendental do que a consciência intencional no seu a priori e em sua função constituinte. O que está em jogo, pois, é...

o imediato e direto vir às claras, portanto a evidência, a clareação
que no seu evidenciar-se é o mostrar-se imediato e concreto, o
aberto, das Offene, a translucidez do luzir, a auto-presença ela
mesma que transcende toda e qualquer objetivação, não a modo
de uma escalação para além da coisa chamada objetivação ou
objeto, mas como "mediação", isto é, como ação ou dinâmica do
médium, a partir e no qual toda e qualquer modalidade de
objetivação e objetos vem a si na aclaração da sua pressuposição,
isto é, o positum da sua auto-mostração. E o que (...)
denominamos captar ou ver simples e imediato. Como, porém, o
termo transcendental de alguma forma conota uma
transcendência a modo do movimento de trânsito para além, a
modo meta-físico, subjetividade transcendental enquanto
clareação transcendental de preferência recebe o nome de
ontologia fundamental (HARADA, 2009, p. 129. Grifo do autor).

Fenomenologia transcendental se torna, assim, método da ontologia fundamental. Difícil é captar a transferência, a relocação (Ortsverlegung), do "lógos" do fenômeno, da consciência (Bewusstsein) para o aberto do ser (das Offene = Dasein), melhor dizendo, para a aberta, a clareira, do ser (Lichtung) (HEIDEGGER, 1986, p. 385). Mais originariamente do que na consciência é na aberta (clareira, fenda, oportunidade) do ser que se loca o lógos dos fenômenos. A presença (Dasein), entendida como abertura do círculo da revelabilidade do ente e de desvelamento do ser, é a locanda, isto é, a tenda, a estância móvel, o tempoespaço, do ser. Em vez de o lógos dos fenômenos estar locado na esfera fechada da consciência, que, ainda que admita a transcendência das coisas a admite como uma transcendência inserida na sua imanência, nesta relocação o lógos dos fenômenos está locado na abertura horizontal-extática da presença (Dasein) (HEIDEGGER, 1986, p. 383-385).

A imediatez da imensidão aberta do ser funda a mediação da consciência intencional. Como? 
Precisamos tornar clara aqui a significação de consciência. $\mathrm{Na}$ consciência (Bewusstsein) jaz o saber (Wissen), que por sua vez está relacionado com o videre, no sentido de que saber é ter visto. A consciência move-se no reino do ver, onde é iluminada pelo lúmen naturale. O que o lumen, a luz, "faz"? Traz clareza. E o que a clareza possibilita? Que eu, antes de tudo, possa chegar às coisas. O verbo francês regarder fala aqui de forma particularmente clara. Regarder significa, de fato, garder, guardar (bewahren), custodiar (ge-wahren) no sentido de: deixar chegar perto de mim o que estou fitando (HEIDEGGER, 1986, p. 379380).

Assim, consciência apenas é ciência, saber, em vendo o que se mostra, o que se deixa re-presentar. Cada forma de consciência, de vivência, de ato, tem sua própria modalidade de evidência. $O$ saber, a ciência da con-sciência, se realiza, a cada vez, numa modalidade própria de evidência, segundo o tipo de intencionalidade da vivência, que está em causa. A evidência, porém, como vidência, se cumpre num ter-visto. Consoante isso, para os gregos, saber é ter visto o "eídos", o aspecto, a fisionomia, a cara em que algo se mostra naquilo que ele é e como ele é. No saber, está em obra um ver (idein) o "eídos" ou a "idéa" de algo, isto é, o seu caráter distintivo, o seu aspecto típico, sua forma (no sentido de forma formadora, germinal, e não de forma formada, terminal; de estrutura estruturante, e não de estrutura estruturada). "Idein", em grego, e "videre", em latim, dizem o mesmo. Saber, conhecer, é, fundamentalmente, ver (simples apreensão, antes que julgamento). O verbo grego "oída", saber, é a forma do pretérito perfeito. Saber é, assim, ter-visto (cf. o aoristo "eídon"). Mas, para que algo seja sabido, é preciso que se manifeste, que se torne patente. $O$ verbo grego "eídoma" diz, justamente, ser visível, aparecer, tornar-se aparecente ou aparente deste ou daquele modo.

Em sua significação tem afinidade com "phaínomar": vir à luz. "Phainómenon" diz, verbalmente, vindo à luz e, nominalmente, o que vem à luz. Para que haja a fenomenalidade do objeto em sua objetualidade para a consciência e a fenomenalidade da própria consciência em sua evidência, é preciso que haja luz (phós, em grego; lumen, em latim). Luz é o medium, no sentido não de intermédio, mas no sentido de meio-elemento, ou seja, no sentido da clareza, em que se dá a visibilidade das coisas, em que elas podem se mostrar em seu viso, em seu visual. Para que haja um direcionamento do humano para as coisas em suas significâncias, isto é, nos modos em que elas se deixam chamar em causa 
e interpelar, é preciso que se dê a clareza. É ela que ao homem ter acesso às coisas, chegar a elas. Para poder se relacionar com as coisas, comportar-se com elas, o homem precisa prestar atenção a elas, carece de tomá-las em consideração, e, nisso, guardá-las e resguardá-las, custodiá-las como o que lhe interessa, fitando-as e deixando-as achegar-se a si naquilo que elas são e como elas são. É preciso, ao mesmo tempo, não perdê-las de vista, e, por outro lado, mantê-las na proximidade, deixando-as ser o que e como elas são.

A clareza é concessão da claridade, do lume (Helle). A clareza da consciência e sua ciência se funda, pois, no lume, dito com outras palavras, na luminosidade, no clarão, no fulgor, no brilho, no fogo arcaico do ser. Só pode haver re-presentação do objeto em sua objetualidade, bem como, mais fundamentalmente, a-presentação e presentação da consciência intencional em sua função constituinte, se a presença (Presenz) própria da consciência se torna para si mesma presente (gegenwärtig), se ela, em sua auto-presença e autoevidência se doa em sua originária datidade (Gegebenheit). Presença (Presenz) supõe vigência (Anwesenheit). O presente é o que está vigente no âmbito da consciência. É um modo de se dar do vigente (das Anwesende). A fenomenalidade da consciência e sua clareza, supõe, pois a claridade, o lume do ser. Mas o lume do ser pressupõe, por sua vez, uma abertura que o deixa-ser. A esta abertura que deixa-ser o lume do ser, em cuja claridade se dá a consciência intencional, com sua clareza, Heidegger chama de "clareira do ser".

Mas o lume, por sua vez, repousa em um campo aberto, livre, que
ele, aqui e ali, vez ou outra, pode clarear. O lume brinca no
descampado e aí entra em contenda com a escuridão. Onde quer
que um vigente se aproxime de outro vigente ou até mesmo
demore em face dele, (...), já reina abertura, está em jogo uma
livre redondeza (freie Gegend). Nós chamamos esta abertura, que
concede um possível deixar-brilhar (Scheinenlassen) e mostrar
(Zeigen), a clareira (die Lichtung) (HEIDEGGER, 1988, p. 71).

O lume do ser, assim, só pode brincar e pôr-se em jogo e, além disso, entrar em luta com a escuridão se reinar a abertura, isto é, o campo aberto, a aberta (como se diz no interior brasileiro). Heidegger fala de "Lichtung" e o correspondente francês "Clairière" (clareira). Parece que "Lichtung" seria um empréstimo tomado do francês "Clairière". Teria sido formado ao modo de palavras arcaicas como "Waldung" (bosque - "Wald" é floresta) e "Feldung" 
(campo - "Feld" é outra palavra para campo). A clareira da floresta (Waldlichtung) é experimentada em oposição à floresta densa, chamado na língua arcaica de "Dickung" (dicht = denso, espesso, cerrado). O substantivo "Lichtung" deriva do verbo "lichten" (rarear). O italiano traduz "Lichtung" por "radura", ou seja, raleadura (sinônimos: rareira, raleira, aberta, clareira, vão). É a abertura do raro, do não denso. É onde a vegetação rareia. Os marinheiros usavam a expressão "lichten" na expressão "den Anker lichten": levantar âncora. "Lichten" significa, assim, tornar leve. Há, pois, uma conexão entre "lichten" e "leichten" (alto-alemão), tornar fácil, maneiro (do latim manuarius, manejável). $O$ adjetivo "licht" é o mesmo que "leicht", leve, ligeiro, tênue, maneiro. A clareira do ser é, assim, a abertura da liberdade, da leveza, do ser. De modo semelhante, ao campo limpo da savana brasileira (do cerrado lato sensu) se opõe o campo denso, o campo cerrado (stricto sensu), ou o cerradão (a região de matas do cerrado lato sensu). $O$ aberto é leve, no sentido de deixa-passar, não só a luz, a claridade, mas também o som, a sonoridade. $O$ aberto é o que deixa-brilhar, mas não só, é também o que deixa soar e ressoar, percutir e repercutir, tinir e retinir. $O$ jogo e a luta do claro-escuro vige a partir daí. Mas também o jogo de sonância e silêncio. O lume do ser e a sonância da linguagem vigem a partir da "clareira". A clareira é o aberto para tudo quanto vem à presença, bem como para toda a ausência. Nas palavras do próprio Heidegger:

A luz, de fato, pode incidir na clareira, em seu aberto, e nela deixar jogar a claridade com a escuridão. Mas a luz nunca cria primeiramente a clareira, contudo, aquela, a luz, pressupõe esta, a clareira. Entretanto, a clareira, a aberta, é livre não apenas para a claridade e a escuridão, mas também para a reverberação e o eco, para o toar e o extinguir-se da tonância. A clareira é $\circ$ aberto para tudo o que advém à presença e tudo o que se ausenta (HEIDEGGER, 1988, p. 72).

O que está em jogo, aqui, não são apenas palavras, "metáforas" ("metáfora" é imagem da linguagem tomada metafisicamente). O que está em jogo, aqui, é coisa, melhor, a coisa do pensar, a coisa da fenomenologia. É o fenômeno não em sentido formal - o que se mostra a si mesmo desde si mesmo. É, antes, o fenômeno des-formalizado. É o fenômeno tomado não em sentido vulgar, como o que se oferece na intuição sensível. Muito menos é o fenômeno privativo (mera aparência) nem o fenômeno remissivo (o fenômeno no sentido da manifestação de 
algo que se anuncia sem se mostrar, mas que se anuncia através de algo que se mostra). O que está em jogo, aqui, é o fenômeno em sentido fenomenológico, isto é, ontológico, radical, originário. É o arqui-fenômeno. Este fenômeno é, ele mesmo, fenomenologia. Por isso, Heidegger evocava o dito de Goethe: „Man suche nur nichts hinter den Phänomenen: sie selbst sind die Lehre" (Só não se busque nada atrás dos fenômenos: eles mesmos são o ensinamento) (HEIDEGGER, 1988, p. 72). Na elucidação de Heidegger: "Isto quer dizer: o fenômeno mesmo, no caso presente a clareira, nos põe diante a tarefa de aprender a partir dele, questionando-o, isto é, de deixá-lo nos dizer algo" (HEIDEGGER, 1988, p. 72). Essa clareira é o que os gregos chamavam de "alétheia".

Orientada por e para a "alétheia", a "clareira do ser", a fenomenologia ganha seu sentido plenamente ontológico. Em Heidegger, a fenomenologia deixa de ser guiada pelo fio condutor da pergunta pela entidade do ente à luz do pensar (Ser e pensar) e passa a se deixar guiar pela "clareira do ser" (Ser e tempo). Do mesmo modo, acontece a relocação do "lógos" do fenômeno, da consciência, para a própria clareira, o medium de todo o vir à presença e de todo o ausentar-se. Antes, o fenômeno precisava da consciência intencional para vir a ser fenomenologia (para constituir-se em seu sentido). Agora não. Agora, o fenômeno é, ele mesmo, fenomenologia. O fenômeno ensina, isto é, nos põe em face à tarefa de aprender, de deixar-nos que ele nos interpele, nos diga, isto é, se nos mostre e nos dê a pensar. Emmanuel Carneiro Leão diz:

\footnotetext{
Em Husserl, é pela intencionalidade que a consciência está sempre passando continuamente do fenômeno para a fenomenologia. Há uma distinção entre fenômeno e fenomenologia e a intencionalidade lhe serve de ponte de ligação e passagem. Sem consciência intencional não se dá fenomenologia.

Em Heidegger, não! O fenômeno já é sempre esta passagem e somente por isso se dá consciência e acontece intencionalidade. Pensar não é função tética de uma consciência transcendental. Pensar é acompanhar as peripécias, as vicissitudes e os percalços desta ininterrupta passagem. Para Husserl, pensar é exercer e exercitar a fenomenologia da consciência. Já para Heidegger, pensar consiste em encontrar-se no Dasein com o Dasein, com a Pre-sença na fenomenologia de todo e em todo o fenômeno (LEÃO, 2013, p. 27).
} 
A clareira é um pressuposto da consciência intencional. Mas não se trata de uma pressuposição construtiva. Trata-se, antes, de uma pressuposição constitutiva. A clareira - a abertura do desvelamento do ser (verdade ontológica), sua liberdade, sua leveza, seu deixar-ser, - é o que possibilita a própria consciência intencional e sua função constituinte. Neste sentido, Heidegger diz:

Sobre que funda-se o ter visto de toda a consciência? Sobre a possibilidade, fundamental para o ser humano, de passar por uma amplidão aberta para chegar a alcançar as coisas.

Este ser-em-uma-amplidão-aberta é precisamente o que "Ser e Tempo" (Heidegger chega a dizer a respeito: "de maneira toda desajeitada e desamparada") (sic) chama Dasein.

Dasein deve ser entendido como o ser-clareira. O Da é, pois, a palavra para a amplidão aberta.

Pode-se ver claramente aqui que a consciência está enraizada no Dasein e não vice-versa (HEIDEGGER, 1986, p. 380).

Desde Heidegger, a investigação fenomenológica consiste em sondar o "ser" na clareira, isto é, na amplidão aberta em que o homem já sempre está, por e para chegar às coisas. É sondar o ser no medium da clareira. Já não significa investigar o ente em sua entidade (objeto em sua objetualidade, sujeito em sua subjetividade, a correlação intencional entre polo noético e noemático, etc.). Significa investigar o lume do ser a partir da clareira do ser. Significa estar atento ao salto originário da liberdade do ser (Ur-sprung: origem). É o salto que deixa-ser a diferença referente entre ente e ser (no sentido de entidade). No Dasein, isto é, na amplidão aberta em que o ser-homem acontece, coincidem os diferentesreferentes ente e ser. Ôntico e ontológico, embora diferentes, se pertencem, sim, coincidem. Temos assim em uno a coincidência de Dasein, ente e ser.

\footnotetext{
Aqui, nessa coincidência, o ponto de incidência não consiste em ser um ponto, fixo constituído, mas sim em tornar-se sempre de novo "ponto de salto". Isto significa que esse ponto não é um quê, mas sim contenção, continência no tinir vigente de prontidão e disposição da espera do inesperado, em cuja in-stância, no instante, i. é, no piscar de olhos, em alemão, im Augenblick, cintila cada vez o evento, o Ereignis. O evento, i. é, o ente, a saber, o em sendo a presença in-stante do já chegado do ainda por vir, a temporalidade, a tempestas, o tempo oportuno como o próprio (eigen) prenhe de ressonância da percussão e repercussão de um toque ou de uma toada, próxima e longínqua. Isto é a aberta do eclodir da clareira, estranhamente simultânea da serenidade e imensidão solta da Liberdade e ao mesmo tempo
} 
um risco, qual raio a rasgar o cintilar de um choque do espanto de uma fenda inexorável a fazer permanecer todas as coisas no susto instantâneo da nitidez da perfilação de cada coisa, a saber, o ente na densidade inexorável da sua identidade como diferença, para de repente, afundar tudo no silêncio do abismo "sem fundo" de uma "caligine" inominável (HARADA, 2004, p. 93).

Fenomenologia se torna, assim, concentração no instante, em que se recolhem e são um o passado como a facticidade da vigência do já ter sido lançado, o futuro como a vigência do advento sempre novo e da sempre nova intromissão do porvir, e a vigência do presente como a sempre nova espera do inesperado. No instante cintila o "Ereignis", isto é, qual evento (Ereignung) que provoca cada ente e, de modo bem peculiar, o homem, seu pensar e dizer, para vir à sua propriedade; qual originário mostrar-se, arqui-fenômeno (Eräugnung). Ser vigora, pois, como originária manifestação (Eräugung = manifestatio) adveniente, sobreveniente, cadente, como proto-acidente, proto-incidente (Eräugnis = eventus, casus). Nesta incidência no eclodir da clareira, coincidem no aberto (tempo-espaço para a verdade do ser - Dasein) ser-e-ente: vige o ser-sendo, vige o sendo-ser. $\mathrm{Na}$ clareira, reina serenidade (Gelassenheit) do deixar-ser o próprio de cada ente, a cada vez. Mas, na clareira, reina também espanto face ao abissal, que nos fita, nos encara, nos interpela. Nela sopra a aragem do sagrado, nela cintila a noite estrelada, a caligem supraluminosa do mistério. Como lemos na narração de Riobaldo, o protagonista do Grande Sertão: Veredas, de Guimarães Rosa: "As coisas assim a gente mesmo não pega nem abarca. Cabem é no brilho da noite. Aragem do sagrado. Absolutas estrelas!" (2019, p. 304).

\section{Referências}

HARADA, H. Heinrich Rombach, memória e gratidão. Revista Scintilla, v. 2, p. 67-96, 2004.

.Iniciação à Filosofia. Teresópolis: Daimon, 2009.

HEIDEGGER, M. Einleitung. Die Idee der Phänomenologie und der Rückgang auf das Bewusstsein. Em E. HUSSERL, Phänomenologische Psychologie (pp. 256-263). Den Haag: Nijhoff, 1968.

Grundfragen der Philosophie: ausgewälte "probleme" der "logik". Frankfurt am Main: Vittorio Klostermann, 1984.

Seminare (GA 15). Frankfurt am Main: Vittorio Klostermann, 1986. 
Zur Bestimmung der Philosophie (Gesamtausgabe Band 56/57). Frankfurt am Main: Vittorio Klostermann, 1987.

Zur Sache des Denkens. Tübingen: Max Niemeyer, 1988.

Die Grundbegriffe der antiken Philosophie (Gesamtausgabe Band 22). Frankfurt am Main: Vittorio Klostermann, 1993a.

Sein und Zeit. Tübingen: Niemeyer, 1993b.

Prolegomena zur Geschichte des Zeitbegriffs (Gesamtausgabe Band 20). Frankfurt am Main: Vittorio Klostermann, 1994.

Wegmarken. Frankfurt am Main: Vittorio Klostermann, 1996.

Vorträge Teil 1: 1915-1932 (Gesamtausgabe Band 80.1). Frankfurt am Main: Vittorio Klostermann, 2016.

$\mathrm{Zu}$ eigenen Veröffentlichungen (Gesammtausgabe Band 82). Frankfurt am Main: Vittorio Klostermann, 2018.

HUSSERL, E. Phänomenologische Psychologie (Husserliana IX). Den Haag: Nijhoff, 1968.

. Ideen zu einer reinen Phänomenologie und phänomenologischen Philosophie. Tübingen: Max Niemeyer, 1993.

LEÃO, E. C. Filosofia Contemporânea. Teresópolis: Daimon, 2013.

ROMBACH, Heinrich; TSUJIMURA, Koichi; OHASCHI, Ryosuke. Sein und Nichts: Grundbilden westlichen und östlichen Denkens. Basel, Freiburg, Wien: Herder, 1981.

ROSA, João Guimarães. Grande Sertão: Veredas - "O diabo na rua, no meio do redemoinho...". São Paulo: Companhia das Letras, 2019 (22ª edição). 